\title{
Investment Decisions through Total Asset Growth toward Price to Book Value on the Jakarta Islamic Index
}

\author{
Syaugi $^{1 *}$, Aulia Rahmah ${ }^{2}$ \\ Universitas Islam Negeri Antasari Banjarmasin, Indonesia.
}

Submitted: 8 May, 2021;Accepted: 12 August 2021; Published: 17 August 2021

\begin{abstract}
This research analyzes the effect of investment decisions through Total Asset Growth (TAG) on Price to Book Value (PBV). Since PVB indicates stock measurement based on the ratio of stock price to book value, it is used by investors to assess the price offered. This research uses time-series data from 2014-2020 to examine seven companies selected using purposive sampling but based on fairly good asset developments from 2014 to 2020. Furthermore, this quantitative causal study data were collected using documentation from various sources and analyzed using a simple linear regression test. The results show that the TAG variable has no effect on PBV. This shows that TAG does not describe a stable company and is not always useful in investment decision-making.
\end{abstract}

Keywords: investment, total asset growth, price to book value. 


\section{INTRODUCTION}

Economic development in a country can be measured by capital market as an investment institution with other important financial and economic functions (Hidayati, 2010; Anggraini, 2015). According to Pardiansyah (2017), capital market is not limited to those with much investment capital. The transactions are also given to companies that need long-term business funding sources (Noerirawan \& Muid, 2012). In economics, one of the capital market functions is to provide funds or investment to those in need (Jozwiak, Marszalek, \& Sekula, 2015). With this investment, the investors hope for a refund from the fresh funds disbursed (Devianasari \& Suryantini, 2015).

The capital market is a characteristic of the economy compared to other markets (Dewi, Adnantara, \& Asana, 2017). This means that its product quality is uncertain but one of the offerings in its activities (Afzal \& Rohman, 2012). Before investing in the capital market, the main requirement is security (Arifah \& Roifah, 2013). This is obtained by getting accurate, clear, and reasonable accounting information as an indicator to assess investment risk by predicting the returns (Nasehah, 2012). Investors in the stock market aim at increasing capital to obtain high profits for themselves and the company with various consequences (Anggraini, 2015). Therefore, a portfolio with a profitable value is needed to determine the value and individual to which the investment is given. This portfolio could be obtained from the bookkeeping reports provided by the company to the public(Wijaya \& Wibawa, 2010).

One of the obligations to be fulfilled for go-public companies is to inform the general public of financial statements (Mukhlis, 2017). Accurate, clear, and broad information is useful for investors to know the company financial condition (Affandi, Sunarko, \& Yunanto, 2019). The basic purpose of investment is to obtain profits through dividends and the difference between buying and selling stocks (capital gains) (Sondakh, 2019). Furthermore, through financial statements, investors assess the company's performance in generating profitability and the amount they would receive(Murniati, Mus, Semmaila \& Nur, 2019).

Investors would be faced with the choice of profit or loss, meaning that they need to always prioritize the precautionary principle before channeling their funds (Devianasari \& Suryantini, 2015). Based on the risk and return by investors, it is common for them to change the form of investment (Rahmanto, 2017). This could create a movement in the capital market as a reflection of changes in investment.

Stock valuation is important information before investing in the capital market. Hartono (2015); and Nasution, Putri and Dungga (2018) stated three valuation indicators used to value stocks, including book, market, and intrinsic values. The three indicators are needed as information to assess the company's growth and development. 
The intrinsic stock value could be determined using the Price to Book Value (PBV) approach. PBV assesses stock sales activities on the capital market and is essential in determining intrinsic value (Wijayanti, Nur \& Setyo, 2016). It describes the value of assets owned by companies, such as securities in the form of stocks (Wijaya \& Wibawa, 2010). The company condition greatly affects the high and low stock prices in the market.

$\mathrm{PBV}$ is a comparison used to evaluate the financial performance of a company. It shows how a company creates value relative to the capital invested with what has been or is being invested by the company owner (Wijayanti et al., 2016). In this case, a company runs well when the PBV ratio is above one or when the market value is higher than the book value (Annisa \& Chabachib, 2017; Sondakh, 2019). Therefore, the higher the PBV value, the greater the additional wealth enjoyed by the owner (Afzal \& Rohman, 2012). Furthermore, according to JII, the high PBV value shows that the market recognizes the company's prospects (Wijayanti et al., 2016).

Pardiansyah (2017) stated that, in purchasing Price to Book Value (PBV), the stock capital market comprises several indicators. These are Total Asset Growth (TAG), Debt to Equity Ratio (DER), and Dividend Payout Ratio (DPR). However, in the capital market, the PBV purchase is more affected by TAG because it is useful as capital in case the company is in a downstate (Zulvia, 2019). This supports Nasution, Putri, and Dungga (2018), which showed that the TAG indicator is one part considered by investors before buying PBV during global economic uncertainty. Furthermore, it becomes the most important part by investors before calculating the DER and DPR. This is because the significant development of TAG is one of their targets during global economic uncertainty (Annisa \& Chabachib, 2017).

Buying a stock means purchasing the future of a company. PBV provides an overview and information about the book value of a company's stock and could include market prices. Therefore, it could be considered for an investor to determine an investment strategy in the capital market. A high PBV value illustrates stockholders' prosperity and gives them consideration and confidence in the company's future condition (Rahmanto, 2017). Investors use PBV to choose which stock to buy, meaning that it predicts overvalued or undervalued stocks (Marlina, 2013).

One of the indicators in determining PBV is TAG in the capital market (Hartono, 2015). Figure 1 presents a graph on the ratio of TAG to PBV in the Jakarta Islamic Index between 2014 and 2020 . 


\section{TAG Rasio toward PBV 2014-2020}

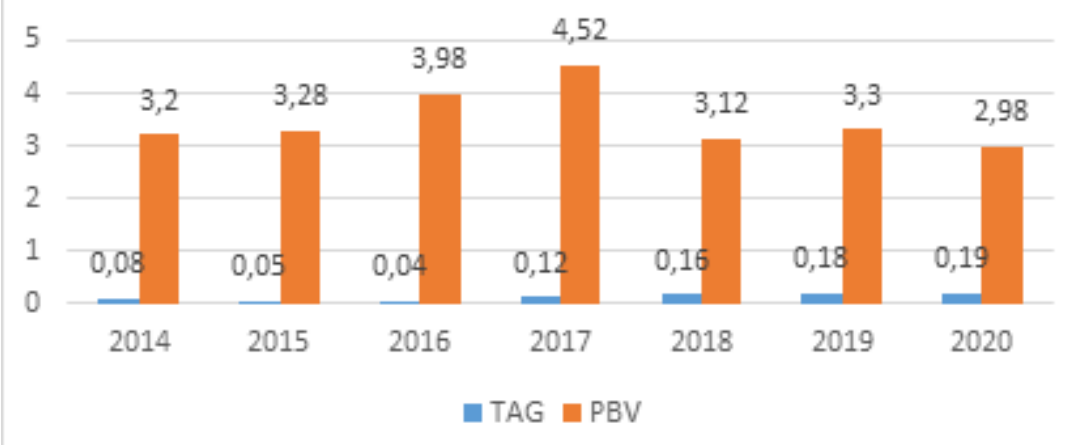

\section{Source: www.idx.co.id (data modification)}

Figure 1. Ratio Graph of TAG toward PBV

Figure 1 shows the differences in the data available in the sample companies from 2014 to 2020, indicating the inconsistency of the relationship between TAG and PBV. TAG decreased by 0.03 between 2014 and 2015 and by 0.01 between 2015 and 2016. It then increased by 0.08 between 2016 and 2017, by 0.04 between 2017 and 2018, by 0.02 in 2019, and by 0.01 in 2020. Furthermore, PVB increased by 0.08 between 2014 and 2015, by 0.70 between 2015 and 2016, by 0.54 between 2016 and 2017, and by 0.08 in 2019. It decreased by 1.40 between 2017 and 2018 and by 0.32 in 2020 due to the current pandemic. However, this inconsistency needs to be tested further because these two variables are interrelated and related theoretically.

The decrease of TAG in 2015 was due to the impact of the global economic recession (Tanjung \& Siregar, 2018). In contrast, this did not affect PBV, whose value increased between 2014 and 2015. Furthermore, the global economy fell in 2020 due to the pandemic, though PBV consistently increased because it was the company's asset deposit during a financial decrease (reference). Fluctuating TAG values and consistent PBV prices make investors believe that TAG is an important indicator taken in investment decision-making (Dewi et al., 2017; Listyaningsih \& Krishnamurti, 2015). An increasing and developing TAG becomes an important company capital, attracting investors' attention (Wijaya \& Wibawa, 2010). However, the effect of TAG on PBV in companies listed on the Jakarta Islamic Index needs to be analyzed by comparing several research timescales.

Several studies examined the effect of Total Asset Growth on Price Book Value and found different results. For instance, Nasehah (2012) and Widyakto and Ariefiantoro (2020) stated that growth did not affect PBV. Conversely, Pangulu and Maski (2014) showed that total asset growth significantly affects PBV. Therefore, TAG on PBV becomes interesting to study. 


\section{METHOD}

This is a causal study with Total Asset Growth as the independent variable while Price to Book Value is the dependent variable (Sugiyono, 2018). The independent variable (Total Asset Growth) is measured by calculating the growth rate of assets with their changes from the previous to the next year. The assets used are for the company's operations, while the dependent value (Price to Book Value) compares the stock price and the book value per share.

This study determines the effect of Total Asset Growth on Price to Book Value with companies listed in the Jakarta Islamic Index (JII) 2014-2020. Purposive sampling was used to select the companies consistently incorporated in the Jakarta Islamic Index (JII) from 2014 to 2020. The selected company had to have a complete annual and financial report and distributed profits to stockholders. Of the 48 companies listed on the Jakarta Islamic Index, only seven companies during the 2014-2020 period at JII were sampled using these criteria. Table 1 shows the seven companies used as research samples.

Table 1. List of 7 Research Sample Companies

\begin{tabular}{ccc}
\hline No. & Stock Code & Issuer Name \\
\hline 1 & ADRO & PT. Adaro Energy Tbk \\
2 & AKRA & PT. AKR Corporindo Tbk. \\
3 & ASII & PT. Astra International Tbk. \\
4 & ICBP & PT. Indofood CBP Sukses Makmur Tbk. \\
5 & INDF & PT. Indofood Sukses Makmur Tbk. \\
6 & UNTR & PT. United Tractors Tbk. \\
7 & UNVR & PT. Unilever Indonesia Tbk. \\
\hline
\end{tabular}

The research sample data is from annual and company financial reports obtained from the Indonesian Capital Market Directory (ICMD) and the Indonesia Stock Exchange through the Indonesia Stock Exchange (IDX). The data were collected using documentation techniques from www.idx.co.id, www.finance.yahoo.com, and www.idnfinance.com to assess companies' developments in JII. They were processed and modified in line with Hartono (2015), which stated that the development of TAG and PBV charts could be assessed using web tools on IDX and Indonesia finance. The hypotheses proposed in this research are as follows:

$\mathrm{H}_{0}=$ There is no effect of TAG toward PBV on companies in the Jakarta Islamic Index.

$\mathrm{H}_{\mathrm{a}}=$ There is an effect of TAG toward PBV on companies in the Jakarta Islamic Index.

Data were analyzed using a simple linear regression with normality and linearity tests. This is consistent with the statement (reference) that hypothesis completion using a purposive sample could be carried out using a linear regression test. It analyzes one independent variable/ predictor $(\mathrm{X})$ with one dependent variable/ response $(\mathrm{Y})$, drawing a gradient between $\mathrm{X}$ and $\mathrm{Y}$ (reference). 


\section{RESULT AND DISCUSSION \\ Data Description}

Table 2 shows Price to Book Value and Total Asset Growth data on seven companies in JII between 2014 and 2020 .

Table 2. Average PBV of Companies at JII During 2014-2020

\begin{tabular}{cccc}
\hline No & Company Code & PBV & TAG \\
\hline 1. & ADRO (USD) & 0,82 & 0,07 \\
2. & AKRA & 2,95 & 0,10 \\
3. & ASII & 2,2 & 0,11 \\
4. & ICBP & 4,19 & 0,10 \\
5. & INDF & 1,42 & 0,05 \\
6. & UNTR & 1,87 & 0,17 \\
7. & UNVR & 12,22 & 0,10 \\
\hline
\end{tabular}

Data adopted from www.idx.co.id; www.finance.yahoo.com; and www.idnfinance.com

The data description results regarding the average TAG and Price to Book Value show that the highest TAG value of the seven companies has the UNTR Company Code of 0.17 with a PBV value of 1.87. Similarly, the lowest TAG has the company code INDF of 0.05 and the PBV value of 1.42. The average shows that a high Total Asset Growth does not provide a high Price to Book Value. This is because investment is not fully measured by asset growth but is based on potential profits.

\section{Research Hypothesis Test}

A prerequisite analysis test was carried out to test the research hypothesis, including normality and linearity tests. The test results are shown as follows:

\section{Normality Test}

Table 3. Normality Test Results on PBV and TAG data

\begin{tabular}{lcccc}
\hline $\begin{array}{l}\text { Analysis Prerequisite } \\
\text { Test }\end{array}$ & Data & Asymp Sig. & $\begin{array}{c}\text { Sig. } \\
\text { Value }\end{array}$ & Description \\
\hline Normality test & PBV & 0,052 & 0,05 & Normally distributed \\
& TAG & 0,200 & 0,05 & Normally distributed \\
\hline
\end{tabular}

The normality test results show that the Asymp Sig value is $>0.05$, meaning that the PBV and TAG data are normally distributed.

\section{Linearity Test}

Table 4. Linearity Test Results on Both Variables

\begin{tabular}{lccl}
$\begin{array}{l}\text { Analysis Prerequisite } \\
\text { Test }\end{array}$ & P-Value & $\begin{array}{c}\text { Sig. } \\
\text { Value }\end{array}$ & Description \\
\hline Linearity test & 0,391 & 0,05 & Linear \\
\hline
\end{tabular}


Table 4 shows the P-value of $0.391>$ sig. 0.05, meaning that the two variables, Price to Book Value and Total Asset Growth, are linear data. Also, the normality and linearity tests have fulfilled the requirements to proceed to the simple linear regression test.

\section{Hypothesis Testing with Simple Linear Regression}

After testing the analysis prerequisites, a simple linear regression test was conducted to test the research hypothesis. This test involves several statistical calculations, such as significance test (t-test), ANOVA, and hypothesis determination. The simple linear regression analysis involved a regression equation that describes the predictive function of the variables affecting other variables (Rusiadi \& Hidayat, 2013). Tables 5 and 6 show the linear regression test results between TAG and PBV.

Table 5. Simple Linear Regression Test Results

\begin{tabular}{cccccc}
\hline Model & Sum of squares & df & Mean Square & F & Sig \\
\hline Regression & 3908.679 & 1 & 3908.679 & 0.021 & 0.890 \\
\hline
\end{tabular}

The simple linear regression test results in Table 5 have a value of 0.890 , indicating that $\mathrm{H} 0$ is accepted. Therefore, Total Asset Growth has no significant effect on Price to Book Value on the Jakarta Islamic Index (JII). This result contradicts the statement that TAG could measure the growth of company assets within a certain period (Rahmanto, 2017). TAG is the ratio between the current and previous total assets of the company to determine investment decisions. According to Zulvia (2019), Devianasari and Suryantini (2015), also Indari (2018), investment should not be measured by asset growth but by profit development as the main consideration for investors. Therefore, the regression analysis confirms that TAG does not affect PBV. Based on the statistical analysis in Table 5, $\mathrm{H}_{\mathrm{o}}$ is accepted, and $\mathrm{H}_{\mathrm{a}}$ is rejected.

Table 6. Coefficient Value

\begin{tabular}{cccccc}
\hline \multirow{2}{*}{ Model } & \multicolumn{2}{c}{$\begin{array}{c}\text { Unstandardized } \\
\text { Coefficient }\end{array}$} & $\begin{array}{c}\text { Standardized } \\
\text { Coefficient }\end{array}$ & \multirow{2}{*}{$\mathrm{t}$} & Sig \\
\cline { 2 - 4 } & $\mathrm{B}$ & Std. Error & Beta & & \\
\hline & 298.500 & 495.544 & & 0.602 & 0.573 \\
TAG & 6.821 & 46.8264 & 0.065 & 0.146 & 0.890 \\
\hline
\end{tabular}

Based on Table 6, the coefficient value in simple linear regression states that the Unstandardized Coefficient value in B is positive at 6.821. This means that TAG does not affect PBV. Furthermore, this result displays the t-test value with sig of $0.890>0.05$, indicating that $\mathrm{H}_{\mathrm{a}}$ is rejected and $\mathrm{H}_{0}$ is accepted. Therefore, the results show that TAG does not affect PBV. 
Table 7. Value of R Square

\begin{tabular}{cc}
\hline $\mathrm{R}$ & $\mathrm{R}$ Square \\
\hline 0,65 & 0,004 \\
\hline
\end{tabular}

The R square value in Table 7 shows the strong effect of TAG on PBV. The analysis shows a value of 0.004 , or a percentage of $4 \%$ on $\mathrm{PBV}$, meaning that $\mathrm{H} 0$ is accepted and $\mathrm{Ha}$ is rejected. Therefore, there is no effect of TAG on PBV.

Investors would continue to invest in the company, even when assets are experiencing a decrease due to the probability that the assets may increase in the future. This supports Hartono (2015), which stated that when the company's assets decrease, there is no certainty certain that they may decrease in the future. An example is PT. Unilever Tbk, with the company code UNVR. The TAG value decreased by 0.04 between 2015 and 2016 (from 0.01 to 0.06), while PBV increased by 0.89 . This implies no direct relationship between TAG values towards PBV, and a decreasing value indicates a decrease in the company's assets. It could be caused by a debt payment or the purchase of new assets (Devianasari \& Suryantini, 2015). These conditions are not detrimental to the company, and investors would still invest.

TAG attracts investors as an offer that the company's assets would continue to grow (Mukhlis, 2017). This could be caused by the value that exceeds the investment capital provided. A decreasing value is not always bad for investors because they consider other assets in the company, such as production locations and movable assets. For this reason, companies with low TAG still attract investors (Salsabila \& Ryandono, 2020; Indari, 2018). This could be due to other factors, and investors believe that the company's asset value would increase over time (Hakim, 2020; Wijayanti et al., 2016).

The TAG value of PT Indofood Sukses Makmur Tbk decreased drastically from 0.07 to -0.1 between 2015 and 2016 and increased by -0.11 to 0.07 between 2016 and 2017. However, the PBV value increased from 1.05 to 1.58 between 2015 and 2016 and decreased from 1.58 to 1.43 between 2016 and 2017. Investors channel money in companies with high TAG values and those with low PBV (Hayati, Saragih, \& Siregar, 2019). This step was taken assuming that the company would optimize the existing TAG to ensure its sustainability (Noerirawan \& Muid, 2012).

Total Asset Growth is greater when the company's activities are good, and some products have basic values, attracting investors (Afzal \& Rohman, 2012). This means that the TAG value could still affect the selling price of a company's attractiveness on the stock market. This is supported by Rahmah and Asnawi (2019) and Annisa and Chabachib (2017) that the Total Asset Growth could be small but still affect the company's value on the stock market. 
It attracts investors to guarantee a company's future (Nasution, Putri, \& Dungga, 2018; Hafifah \& Fitriany, 2012), even when it has a small value. Therefore, investors find it attractive, hoping that the company keeps developing, as reflected in financial books.

Total Asset Growth symbolizes a company's prosperity in the stock development (Hartono, 2015) and describes an implication of profits. However, investors also consider their survival in times of crisis with significant TAG growth (Salsabila \& Ryandhono, 2020). An example was during the beginning of the pandemic when the stock market decreased and even sold to stabilize the company (Widyakto \& Ariefiantoro, 2020). Therefore, when purchasing Price to Book Value, investors no longer focus only on Total Asset Growth but also on the potential profits.

\section{CONCLUSION}

This research shows that the Total Asset Growth variable does not significantly affect the Price to Book Value of companies in the Jakarta Islamic Index in the 2014-2020 period. This is because investment is not fully measured by asset growth but is based on the potential profits for investors. Furthermore, a decreasing TAG value is not always bad for investors. Therefore, they should not rely on TAG in making investments but consider other assets in the company. However, this research has not described its condition during the Covid-19 pandemic. This is because the data provided by the Indonesia Stock Exchange (IDX) did not fully summarize the current stock market conditions. Therefore, further research should examine the development of TAG on PBV during the Covid-19 pandemic. This would serve as a reference for investors in making PBV purchasing decisions during a pandemic.

\section{REFERENCES}

Affandi, F., Sunarko, B., \& Yunanto, A. (2019). The Impact of Cash Ratio, Debt to Equity Ratio, Receivables Turnover, Net Profit Margin, Return on Equity, and Institutional Ownership to Dividend Payout Ratio. Journal of Research in Management, 1(4), 1-11. https://doi.org/10.32424/jorim.v1i4.53.

Afzal, A., \& Rohman, A. (2012). Pengaruh Keputusan Investasi, Keputusan Pendanaan dan Kebijakan Dividen terhadap Nilai Perusahaan. Diponegoro Journal of Accounting, $1(1), 1-9$.

Anggraini, R. (2015). Analisis Pengaruh Price Earning Ratio (PER), Debt to Equity Ratio (DER), Return on Asset (ROA), Current Ratio (CR) dan Firmsize Terhadap Nilai Perusahaan (PBV) pada Perusahaan Sektor Property, Real Estate \& Building Construction yang Terdaftar di Bursa Efek Indonesia (BEI) Tahun 2008-2012. Skripsi. Semarang: Universitas Dian Nuswantoro. 
Arifah, D. A., \& Roifah, S. (2013). The Effect of Investment Decision, Funding Decision \& Dividend Policy on Corporate Value. Journal of Economics, 5(1), 1-7.

Annisa, R., \& Chabachib, M. (2017). Analisis Pengaruh Current Ratio (CR), Debt to Equity Ratio (DER), Return on Assets (ROA) terhadap Price to Book Value (PBV), dengan Dividend Payout Ratio sebagai Variabel Intervening (Studi Kasus Pada Perusahaan Industri Manufaktur yang Terdaftar di BEI Periode 2011-2014). Diponegoro Journal of Management, 6(1), 1-15.

Devianasari, N. L., \& Suryantini, N. P. S. (2015). Pengaruh Price Earnings Ratio, Debt to Equity Ratio, dan Dividen Payout Ratio terhadap Nilai Perusahaan pada Perusahaan Manufaktur yang Terdaftar di Bursa Efek Indonesia. E-Jurnal Manajemen Unud, 4(11), 3646-3674.

Dewi, N. N. S. R. T., Adnantara, K. F., \& Asana, G. H. S. (2017). Modal Investasi Awal dan Persepsi Risiko dalam Keputusan Berinvestasi. JIA (Jurnal Ilmiah Akuntasi), 2(2). 179-130. https://doi.org/http://dx.doi.org/10.23887/jia.v2i2.15636.

Hakim, M. Z. (2020). Pengaruh Makro Ekonomi terhadap Indeks Saham di Jakarta Islamic Index (JII). I-Economics: A Research Journal on Islamic Economics, 6(2), 194-206. https://doi.org/https://doi.org/10.19109/ieconomics.v6i2.6439.

Hafifah N. \& Fitriany. (2012). Pengaruh Beban Kerja, Pengalaman Audit dan Tipe Kepribadian terhadap Skeptisisme Profesional dan Kemampuan Auditor dalam Mendeteksi Kecurangan. Prosiding Simposium Nasional Akuntansi XV Banjarmasin.

Hartono, J. (2015). Teori Portofolio dan Analisis Investasi (10th ed.). Yogyakarta: BPFE.

Hayati, I., Saragih, D. H., \& Siregar, S. (2019). The Effect of Current Ratio, Debt to Equity Ratio, and ROA on Stock Prices in Sharia-Based Manufacturing Companies in Indonesia Stock Exchange. Proceeding International Seminar of Islamic Studies. 1(1), 276-290.

Hidayati, E. E. (2010). Analisis Pengaruh DER, DPR, ROE dan Size terhadap PBV Perusahaan Manufaktur yang Listed di BEI Periode 2005-2007. Jurnal Bisnis Strategi, 19(2), 166-174. https://doi.org/https://doi.org/10.14710/jbs.19.2.166-174.

Indari, Y. (2018). Pengaruh Kapitalisasi Jakarta Islamic Index (JII) dan Indeks Saham Syariah Indonesia (ISSI) terhadap Outstanding Sukuk Korporasi di Indonesia Tahun 20152017. Medina-Te: Jurnal Studi Islam, 19(2), 90-107. https://doi.org/https://doi.org/ https://doi.org/10.19109/medinate.v14i2.3079.

Jóźwiak, B. K., Marszałek, J., \& Sekula, P. (2015). Determinants of Debt-Equity Choice Evidence from Poland. Emerging Market Journal, 5(2), 1-8. https://doi.org/10.5195/ emaj.2015.76. 
Listyaningsih, E \& Krishnamurti, C. (2015). How Performance of Jakarta Islamic Index (JII)

Stocks Relative to Other Stocks?. Jurnal Dinamika Manajemen, 6(2), 145-164.

Marlina, T. (2013). Pengaruh Earning Per Share, Return on Equity, Debt to Equity Ratio dan Size terhadap Price to Book Value. Jurnal Ilmiah Akuntansi Kesatuan, 1(1), 59-72.

Mukhlis. (2017). Pengaruh Faktor Fundamental terhadap Price to Book Value pada Perusahaan Manufaktur yang Terdaftar di Bursa Efek Indonesia Tahun 2011 - 2014. Tugas Akhir. Tanjung Pinang: Fakultas Ekonomi Universitas Maritim Raja Ali Haji.

Murniati, S., Mus, A. R., Semmaila, B., \& Nur, A. N. (2019). Effect of Investment Decisions, Financing Decisions, and Dividend Policy on Profitability and Value of the Firm. International Journal of Accounting Finance in the Asia Pacific, 2(1). 1-10. https://doi.org/https://doi.org/10.32535/ijafap.v2i1.359.

Nasehah, D. (2012). Analisis Pengaruh ROE, DER, DPR, Growth dan Firm Size terhadap Price Book Value (PBV) (Studi Kasus pada Perusahaan Manufaktur yang Listed di BEI Periode Tahun 2007-2010). Skripsi. Semarang: Universitas Diponegoro.

Nasution, A. E., Putri, L. P., \& Dungga, S. (2018). The Effect of Debt to Equity Ratio and Total Asset Turnover on Return on Equity in Automotive Companies and Components in Indonesia. Proceedings of the 3rd International Conference on Accounting, Management and Economics (ICAME). 92, 182-188. https://doi.org/10.2991/icame18.2019.20.

Noerirawan, M. R., \& Muid, A. (2012). Pengaruh Faktor Internal dan Eksternal Perusahaan terhadap Nilai Perusahaan (Studi Empiris pada Perusahaan Manufaktur yang Terdaftar di Bursa Efek Indonesia Periode 2007-2010). Diponegoro Journal of Acounting, 1(1), $582-593$.

Pangulu, A. L., \& Maski, G. (2014). Pengaruh Profitabilitas, Growth Opportunity dan Struktur Modal terhadap Nilai Perusahaan (Studi pada Perusahaan Perbankan yang Terdaftar di Bursa Efek Indonesia Periode 2011-2013). Jurnal Ilmiah Mahasiswa FEB, 3(1), 1-13.

Pardiansyah. E. (2017). Investasi dalam Perspektif Ekonomi Islam: Pendekatan Teoritis dan Empiris. Economica: Jurnal Ekonomi Islam, 8(2), 337-373. https://doi.org/10.21580/ economica.2017.8.2.1920.

Rahmah, S., \& Asnawi, H. F. (2019). Pengaruh Current Ratio dan Debt to Equity Ratio terhadap Return of Equity pada Perusahaan yang Terdaftar dalam Jakarta Islamic Index (Studi di Sub-Sektor Telekomunikasi Periode 2013-2017). At Taradhi: Jurnal Studi Ekonomi, 10(2), 202-213. https://doi.org/http://dx.doi.org/10.18592/attaradhi.v10i2.3285.

Rahmanto, M. R. A. (2017). Pengaruh Keputusan Investasi, Keputusan Pendanaan dan Kebijakan Dividen terhadap Nilai Perusahaan pada Perusahaan Manufaktur yang 
Terdaftar di Bursa Efek Indonesia. Skripsi. Yogyakarta: Universitas Negeri Yogyakarta.

Rusiadi, R., \& Hidayat, R. (2013). Metode Penelitian, Manajemen, Akuntansi dan Ekonomi Pembangunan. Konsep, Kasus dan Aplikasi SPSS, Eviews, Amos dan Lisrel. Medan: USU Press.

Salsabila, R. N., \& Ryandono, M. N. H. (2020). Determinan Nilai Pasar Saham Syariah di Jakarta Islamic Index (JII). Jurnal Ekonomi Syariah Teori dan Terapan, 7(8), 1552-1565. https://doi.org/10.20473/vol7iss20208pp1552-1565.

Sondakh, R. (2019). The Effect of Dividend Policy, Liquidity, Profitability and Firm Size on Firm Value in Financial Service Industries Listed in Indonesia Stock Exchange 20152018 Period. Journal Accountability, 8(2), 91-101.https://doi.org/https://doi.org/10. 32400/ja.24760.8.2.2019.91-101.

Sugiyono. (2018). Metode Penelitian Kuantitatif, Kualitatif dan $R \&$ D (28th ed.). Bandung: Alfabeta.

Tanjung, H., \& Siregar, T. A. M. (2018). Analisis Votalitas Saham di Jakarta Islamic Index (JII) Periode Januari 2015-Januari 2018. Ihtifaz: Journal of Islamic Economics, Finance, and Banking, 1(1), 147-157. https://doi.org/10.12928/ijiefb.v1i1.270.

Wijaya, L. R. P., \& Wibawa, A. (2010). Pengaruh Kepetusan Investasi, Keputusan Pendanaan dan Kebijakan Dividen Terhadap Nilai Perusahaan. Prosiding Simposium Nasional Akuntansi XIII.

Wijayanti, I., Nur, D. I., \& Setyo, G. (2016). Analisis Nilai Perusahaan Pada Sektor Pertambangan Batubara di Bursa Efek Indonesia. Ekuilibrium: Jurnal Ilmiah Bidang Ilmu Ekonomi, 11(2), 107-130.https://doi.org/https://doi.org/10.24269/ekuilibrium. v11i2.211.

Widyakto, A. \& Ariefiantoro, T. (2020). Pengaruh Total Asset, Growth, dan DER, terhadap Nilai Perusahaan dengan ROA Sebagai Variabel Mediasi (Studi Pada Perusahaan Manufaktur yang Listed di Bursa Efek Indonesia Tahun 2014-2016). Solusi: Majalah Ilmiah Fakultas Ekonomi Universitas Semarang, 18 (2), 173-192.http://dx.doi.org/ 10.26623/s1si.v18i2.2305.

Zulvia, Y. (2019). Pengaruh Debt to Equity Ratio (DER) dan Debt to Total Asset Ratio (DAR) terhadap Profitability pada Perusahaan Manufaktur yang Terdaftar di Bursa Efek Indonesia (BEI) Periode 2014-2017. Economac: Jurnal Ilmiah Ilmu Ekonomi, 3(2), 19. https://doi.org/https://doi.org/10.24036/economac/vol3-iss2/93. 